American Journal of Biochemistry and Biotechnology 5 (2): 84-93, 2009

ISSN 1553-3468

(C) 2009 Science Publications

\title{
Degradative Plasmid and Heavy Metal Resistance Plasmid Naturally Coexist in Phenol and Cyanide Assimilating Bacteria
}

\author{
Bahig El.Deeb and Abdullah D. Altalhi \\ Department of Biological Science, Faculty of Science, \\ Taif University, Taif 888, Saudia Arabia
}

\begin{abstract}
Problem statement: Heavy metals are known to be powerful inhibitors of xenobiotics biodegradation activities. Alleviation the inhibitory effect of these metals on the phenol biodegradation activities in presence of heavy metals resistant plasmid was investigated. Approach: Combination of genetic systems of degradation of xenobiotic compound and heavy metal resistance was one of the approaches to the creation of polyfunctional strains for bioremediation of soil after co-contamination with organic pollutants and heavy metals. Results: A bacterial strain Pseudomonas putida $\mathrm{PhCN}$ (pPhCN1, pPhCN2) had been obtained. This bacterium contained two plasmids, a $120 \mathrm{~Kb}$ catabolic plasmid that encode for breakdown of phenol ( $\mathrm{pPhCN} 1)$ and $\mathrm{pPhCN} 2$ plasmid $(100 \mathrm{~Kb})$ that code for cadmium and copper resistant. Cyanide assimilation by this bacterium was encoded by chromosomal genes. The inhibitory effect of cadmium $\left(\mathrm{Cd}^{2+}\right)$ or copper $\left(\mathrm{Cu}^{2+}\right)$ on the degradation of phenol and cyanide by $P$. putida strains PhCN and PhCN1 (contained pPhCN1) were investigated. The resistant strain $\mathrm{PhCN}$ showed high ability to degrade phenol and cyanide in presence of $\mathrm{Cd}^{2+}$ or $\mathrm{Cu}^{2+}$ comparing with the sensitive strain PhCN1. In addition, $\mathrm{Cd}^{2+}$ or $\mathrm{Cu}^{2+}$ was also found to exert a strong inhibitory effect on the $\mathrm{C} 23 \mathrm{O}$ dioxygenase enzyme activity in the presence of cyanide as a nitrogen source. Conclusion: The presence of heavy metal resistance plasmid alleviated the inhibitory effect of metals on the phenol and cyanide assimilation by resistant strain.
\end{abstract}

Key words: Bacteria, cadmium, copper, plasmid, phenol degradation

\section{INTRODUCTION}

Forty percent of hazardous wastes on the Environmental Protection Agency's (EPA) National Priority List (NPL) are co-contaminated with organic and heavy metals pollutants that pose healthy hazards to humans and wildlife ${ }^{[12,23]}$. Common organic pollutants at these sites include phenol, Polycyclic Aromatic Hydrocarbons (PAHs), chlorinated solvents, cyanide, herbicide and pesticides, while common heavy metal contaminants include arsenic, cadmium, chromium, copper, lead, mercury, nickel and zinc. Isolation of bacterial strains that are able to degrade more than one organic pollutants such as phenol and cyanide, is becoming increasingly important for decontaminating polluted soil, sledges and ground water ${ }^{[7,13]}$. The use of these microorganisms may face various problems, including poor survival, substrate accessibility ${ }^{[16]}$, or the presence of inhibitory compounds. Heavy metals are known to be powerful inhibitors of biodegradation activities $^{[2,25-27,29]}$, thus, their presence may impair the biodegradation of aromatic compounds in polluted sites $^{[5,15,16,24,25,29-32,34]}$. Situations where simultaneous contamination by heavy metals and organic compounds are present can be expected and have been detected in industrial areas ${ }^{[1]}$. For this reason, there is increasing interest $^{[33]}$ in bacterial strains that degrade aromatic compounds and tolerate toxic metals. It has previously been shown that strains of Alcaligenes eutrophus bearing plasmids of metal resistance and plasmids of biodegradation of polychlorinated biphenyls and 2,4dichlorophenoxyacetic acid degrade these xenobiotics more effectively in the presence of nickel or zinc as compared with sensitive strain ${ }^{[6,32]}$. However, to date, there have been no data on the interaction of genetic systems of aromatic compounds degradation, cyanide assimilation and metal resistance and their effect on physiology, biodegradation efficiency and the activity of the key enzyme in multifunctional strains.

The objective of this study was to examine the physiological and biochemical features of phenol degradation in variants of the soil strain $P$. putida $\mathrm{PhCN}$ sensitive and resistant to heavy metals, in presence of three toxicants, cadmium $\left(\mathrm{Cd}^{2+}\right)$, copper $\left(\mathrm{Cu}^{2+}\right)$ and cyanide, as a nitrogen source.

Corresponding Author: Bahig El Deeb, Department of Biological Science, Faculty of Science, Taif University, Taif 888, Saudia Arabia Tel: 0966503158713 
Am. J. Biochem. \& Biotech., 5 (2): 84-93, 2009

\section{MATERIALS AND METHODS}

Chemical: Phenol, Agarose and ethidium bromide were purchased from Sigma (St. Lous, MO, USA). Sodium cyanide, cadmium chloride $\left(\mathrm{CdCl}_{2}\right)$, nickel chloride $\left(\mathrm{NiCl}_{2}\right)$, zinc chloride $\left(\mathrm{ZnCl}_{2}\right)$ and copper chloride $\left(\mathrm{CuCl}_{2} .2 \mathrm{H}_{2} \mathrm{O}\right)$ were procured from Merck (Darmstadt, Germany). Bacteriological media were purchased from Difco (Difco Laboratories, Detroit, Michigan) and Oxoid (Oxoid Inc., Nepean, Ontario). Reagents compounds used were of the highest grade commercially available.

Bacterial strains, plasmids and culture conditions: Bacterial strains and plasmids used in this study are shown in Table 1. P. putida strain PhCN was isolated from Agriculture soil contaminated with different pesticides. This stain completely degraded phenol and cyanide as a sole source of carbon and nitrogen respectively ${ }^{[9]}$. PhCN1 (pPhCN1), PhCN2 (pPhCN2) and $\mathrm{PhCNM}$ (plasmidless) strains were the cured derivatives of wild type strain P. putida $\mathrm{PhCN}^{[9]}$. All isolates were grown aerobically at $30^{\circ} \mathrm{C}$ on a rotary shaker at $150 \mathrm{rpm}$ in Luria-Bertani (LB) medium ${ }^{[27]}$ or Tris-buffered (MSM), which was prepared according to Mergeay et al. ${ }^{[20]}$. All isolates were maintained either on nutrient agar slants at $4^{\circ} \mathrm{C}$ or in $20 \%(\mathrm{v} / \mathrm{v})$ glycerol solution at $-80^{\circ} \mathrm{C}$.

Effect of the presence of heavy metals on the growth of $P$. putida PhCN and its derivatives: Bacterial cells were pre-grown in MSM with phenol $(1 \mathrm{mM})$ and cyanide $(0.5 \mathrm{mM})$ in Erlenmeyer flasks at $28^{\circ} \mathrm{C}$ $(150 \mathrm{rpm})$ until an optical density $\left(\mathrm{OD}_{600}\right)$ of about 0.5 was reached. This culture $\left(2.2 \times 10^{5}\right)$ was used to inoculate Erlenmeyer flasks containing $1 \mathrm{mM}$ phenol and ammonium and/or cyanide as the sole source of carbon and nitrogen, respectively. The concentrations of studied heavy metals were adjusted to 10 or $100 \mu \mathrm{M}$. The initial $\mathrm{OD}_{600}$ was adjusted to about 0.05. Control flasks contained free metals medium inoculated with the same studied strains. All cultures were incubated on an orbital shaker $(150 \mathrm{rpm})$ at $28^{\circ} \mathrm{C}$. $\mathrm{OD}_{600} \mathrm{~nm}$ was determined periodically and used as the measure of growth to construct growth curves and assess heavy metal effects on biodegradation as described by ${ }^{[18,34]}$. All tests were done in triplicate.
Analytical methods: The phenol degradation was determined by monitoring the change in phenol concentration ${ }^{[10]}$. At different intervals of incubation, $1 \mathrm{~mL}$ samples were taken and transferred to an Eppendorff tube containing $25 \mu \mathrm{L}$ of $2 \% \quad 4-$ aminoantipyrene and $50 \mu \mathrm{L}$ of $2 \mathrm{M}$ ammonia. After mixing, $25 \mu \mathrm{L}$ of $8 \%$ potassium hexacyanoferrate (III) was added. The suspension was centrifuged at $5,000 \times \mathrm{g}$ for $2 \mathrm{~min}$ and absorbance at $500 \mathrm{~nm}$ was measured and compared with phenol standards curve.

Cyanide determination: Cyanide concentration was determined by a modification of picric acid as described by Myers et al. ${ }^{[21]}$. Linear calibration curve was obtained with the standard cyanide solution as follow: Aliquots $0.05 \mathrm{~mL}$ of cyanide-containing solution (after centrifugation at $15,000 \mathrm{~g}$ for $10 \mathrm{~min}$ at $4^{\circ} \mathrm{C}$ ) was added to $0.1 \mathrm{~mL}$ aliquots of solution containing $0.5 \%(\mathrm{w} / \mathrm{v})$ picric acid and $0.25 \mathrm{M} \mathrm{Na} 2 \mathrm{CO} 3$. The resulting solution were placed in boiling water-bath for $5 \mathrm{~min}$, diluted to $1 \mathrm{~mL}$ with $0.85 \mathrm{~mL}$ distilled water and cooled in tap water for $30 \mathrm{~min}$. The absorbance was read at $520 \mathrm{~nm}$ against a blank of distilled water and picric acid reagent.

Determination of Minimal Inhibitory Concentration (MIC) of $\mathrm{Cd}^{2+}, \mathrm{Cu}^{2+}, \mathrm{Ni}^{2+}$ and $\mathrm{Zn}^{2+}$ against studied bacterial variants: Minimum inhibitory concentrations (MIC) of metals for each isolate was determined by the plate-dilution method as adopted by Mergeay et al.$^{[20]}$. The metals $\mathrm{Cd}^{2+}, \mathrm{Cu}^{2+}, \mathrm{Ni}^{2+}$ and $\mathrm{Zn}^{2+}$ were used as $\mathrm{CdCl}_{2}, \mathrm{CuCl}_{2} \cdot 2 \mathrm{H}_{2} \mathrm{O}, \mathrm{NiCl}_{2}$ and $\mathrm{ZnCl}_{2}$, respectively, in various concentrations ranging from $0.001-8 \mathrm{mM}$. The plates were incubated at $28-30^{\circ} \mathrm{C}$ for $72-96 \mathrm{~h}$. The concentration of metal which permitted growth and beyond which there was no growth was considered as the MIC of the metal against the strain tested. Carbon free Tris-salt medium (MSM) with $1.5 \%$ agar, containing phenol and ammonium or cyanide as a sole source of carbon and nitrogen respectively, was also used for detection of tolerance against these metals. The concentration of added phenol and cyanide in the media was 1 and $0.5 \mathrm{mM}$, respectively.

Table 1: Bacterial strains and plasmids

\begin{tabular}{lll}
\hline Strains or plasmid & Relevant characteristic(s)a & Reference or source \\
\hline Pseudomonas putida: & & {$[9]$} \\
PhCN & $\mathrm{Ph}^{+}, \mathrm{Cd}^{\mathrm{r}}, \mathrm{Cu}^{\mathrm{r}}$, wild type $\mathrm{pPhCN} 1, \mathrm{pPhCN} 2$ carrier & {$[9]$} \\
PhCN1 & $\mathrm{Ph}^{+}$a cured mutant of PhCN, pPhCN1 carrier & Present study \\
PhCN2 & $\mathrm{Cd}^{\mathrm{r}}, \mathrm{Cu}^{\mathrm{r}}$ a cured mutant of PhCN, pPhCN2 carrier & {$[9]$} \\
PhCNM & $\mathrm{Ph}^{-}, \mathrm{Cd}^{-}, \mathrm{Cu}$ a cured mutant of PhCN, Plasmidless & {$[9]$} \\
Plasmids & & Present study \\
pPhCN1 & $120 \mathrm{~Kb} \mathrm{Ph}^{+}$catabolic plasmid of $P$. putida $\mathrm{PhCN}$ & \\
pPhCN2 & $100 \mathrm{~Kb} \mathrm{Cd}^{\mathrm{r}}, \mathrm{Cu}^{\mathrm{r}}$, , heavy metal resistant plasmid of $P$. putida $\mathrm{PhCN}$ & \\
\hline
\end{tabular}


Preparation and crude enzyme extract: The effect of $\mathrm{Cd}^{2+}$ or $\mathrm{Cu}^{2+}$ was studied at the same concentration, previously mentioned for studying the effect on growth and phenol degradation. P. putida strain $\mathrm{PhCN}$ and its derivatives were grown overnight in MSM containing $0.5 \mathrm{mM}$ phenol. Then, the culture was diluted in fresh LB medium, LB medium plus $0.5 \mathrm{mM}$ phenol, or MSM containing either ammonium or $\mathrm{KCN}$ as a sole nitrogen source and $0.5 \mathrm{mM}$ phenol as a carbon source. Cells were harvested by centrifugation at $10,000 \times \mathrm{g}$ for $10 \mathrm{~min}$ at $4^{\circ} \mathrm{C}$. The pellets were washed twice in $50 \mathrm{mM}$ phosphate buffer and were disrupted sonically at $4^{\circ} \mathrm{C}$. Cellular debris was removed by centrifugation $\left(12,000 \times \mathrm{g}\right.$ for $20 \mathrm{~min}$ at $\left.4^{\circ} \mathrm{C}\right)$. The enzymes activity were measured by incubating the crude enzymes extract with $100 \mu \mathrm{M}$ catechol or phenol in $33 \mathrm{mM}$ Tris- $\mathrm{HCl}$ ( $\mathrm{pH} 8.0$ ), containing $1.3 \mathrm{mM}$ EDTA and $3.3 \mathrm{mM} 2-$ mercaptoethanol, at $25^{\circ} \mathrm{C}$. The activity of catechol-2,3dioxygenase was determined from the rate of $\alpha$ oxymuconic semialdehyde ormation $(\alpha=375 \mathrm{~nm}$, $\mathrm{E}=33.4 \mu \mathrm{M} \mathrm{cm}$ ). The activity of catechol-1,2 dioxygenase was determined from the rate of cis-cis muconate formation $\left(\alpha=260, \mathrm{E}=16.9 \mu \mathrm{M} \mathrm{cm}^{-1}\right)$. The specific enzyme activity was expressed in nano moles of the cofactor consumed or the product formed in $1 \mathrm{~min}$ $1 \mathrm{mg}^{-1}$ of total bacterial protein. The protein concentration was determined spectrophotometrically according to Lowery et al. ${ }^{[17]}$.

Plasmid analysis: Plasmids were analyzed from cells grown in liquid media under selective conditions given by either metals or the carbon source. Plasmids of $P$. putida $\mathrm{PhCN}$ strains and its derivatives were analyzed according to the method of Kado and $\mathrm{Liu}^{[14]}$. Standard DNA techniques were used as described previously $^{[28]}$. For plasmids analysis, $0.7 \%(\mathrm{wt} / \mathrm{vol})$ agarose gels with Tris borate-EDTA buffer were employed. The size estimate of the isolated plasmid was obtained by comparing relative mobility on agarose gel with standard molecular markers.

\section{RESULTS AND DISCUSSION}

Native plasmids in $P$. putida PhCN: Plasmid DNA analysis of $P$. putida strain PhCN cultures grown on phenol and cyanide indicated the presence of two large plasmid elements ${ }^{[9]}$. Plasmid curing experiments produced a plasmid-free strain named as PhCNM, a variant containing the $120 \mathrm{~kb}$ plasmid ( $\mathrm{pPhCN} 1)$ named as $\mathrm{PhCN} 1$ and a strain harboring $100 \mathrm{~kb}$ plasmid (pPhCN2) named as PhCN2. Based on the fact that subsequent plasmid curing experiments demonstrated that the ability to utilize phenol was encoded by the
$120 \mathrm{~kb}$ plasmid, whereas the ability to utilize cyanide appeared to be encoded by the chromosome ${ }^{[9]}$.

Each plasmid in these variants was remained stable and retained the determined phenotype phenol degradation $\left(\mathrm{ph}^{+}\right)$and/or heavy metal resistance $\left(\mathrm{cd}^{\mathrm{r}} / \mathrm{Cu}^{\mathrm{r}}\right)$ after several passages in non selective medium. In the wild type strain $\mathrm{PhCN}$ (contained pPhCN1, pPhCN2), both plasmids were also maintained stably and retained the determined phenotype of $\mathrm{ph}^{+}$and $\mathrm{Cd}^{\mathrm{r}} / \mathrm{Cu}^{\mathrm{r}}$ after several passages in a non selective medium.

Minimal Inhibitory Concentration (MIC) of $\mathrm{Cd}^{2+}$, $\mathrm{Cu}^{2+}, \mathrm{Ni}^{2+}$ and $\mathrm{Zn}^{2+}$ against studied bacterial variants: In the preliminary screening, the ability of $P$. putida $\mathrm{PhCN}$ and its derivatives; $\mathrm{PhCN} 1, \mathrm{PhCN} 2$ and $\mathrm{PhCNM}$, to form confluent growth in the presence of incremental concentrations of studied metal salts was evaluated. On complete medium (LB), the wild type strain $\mathrm{PhCN}$ exhibited the highest resistance to $\mathrm{Cd}^{2+}$ and $\mathrm{Cu}^{2+}$ in comparison with the other variants, $\mathrm{PhCN} 1$ and PhCNM (Table 2). However, the MICs of $\mathrm{Zn}^{2+}$ and $\mathrm{Ni}^{2+}$ for tested variants were very close.

It has been previously demonstrated that the interference of a high phosphate content in the usual minimal medium with a metal effect can lead to the over estimation of the $\mathrm{MIC}^{[20]}$. Therefore, in the present study, levels of resistance in wild type strain $\mathrm{PhCN}$ and its cured derivatives to $\mathrm{Zn}^{2+}, \mathrm{Cu}^{2+}, \mathrm{Ni}^{2+}$ and $\mathrm{Cd}^{2+}$ were determined on Tris-medium supplemented with glucose as the sole carbon and energy source. As presented in Table 2, for the resistance variant $\mathrm{PhCN}$, MIC of $\mathrm{Cd}^{2+}$ $(1.5 \mathrm{mM})$ and $\mathrm{Cu}^{2+}(1.2 \mathrm{mM})$ were much higher than in sensitive strain PhCN1 (0.03 and $0.02 \mathrm{mM}$ for $\mathrm{Cd}^{2+}$ and $\mathrm{Cu}^{2+}$, respectively). No significant difference in the MICs of $\mathrm{Zn}^{2+}$ and $\mathrm{Ni}^{2+}$ among the four strains were observed. Furthermore, the MICs of $\mathrm{Cd}^{2+}, \mathrm{Zn}^{2+}, \mathrm{Cu}^{2+}$ and $\mathrm{Ni}^{2+}$ for tested strains in the Tris-medium were lower than those observed in the LB medium (Table 2). This result was in harmony with those mentioned by Mergeay et al. ${ }^{[20]}$. They stated that MICs of heavy metals in Tris-medium were lower than those observed in a rich medium. On the other hand, the MICs of $\mathrm{Cd}^{2+}$, $\mathrm{Zn}^{2+}, \mathrm{Cu}^{2+}$ and $\mathrm{Ni}^{2+}$ in presence of phenol and cyanide as sole carbon and nitrogen sources, respectively, for tested strains were lower than those observed in the Tris-medium supplemented with glucose and ammonium as sole carbon and nitrogen sources, respectively (Table 2). These results are consistent with findings of $^{[4]}$ that the MICs of metals for catabolic strains in the presence of aromatic compounds as the only source of carbon are only slightly lower than those evaluated in the presence of glucose or malate. 
Am. J. Biochem. \& Biotech., 5 (2): 84-93, 2009

Table 2: MICs of heavy metals for Pseudomonas putida $\mathrm{PhCN}$ and its derivatives in different cultural conditions

\begin{tabular}{|c|c|c|c|c|c|c|c|c|c|c|c|c|c|c|c|c|}
\hline \multirow[b]{2}{*}{$\begin{array}{l}\text { Bacteril } \\
\text { strains }\end{array}$} & \multicolumn{4}{|c|}{ MIC of $\mathrm{Cd}^{2+}(\mathrm{mM})$} & \multicolumn{4}{|c|}{ MIC of $\mathrm{Cu}^{2+}(\mathrm{mM})$} & \multicolumn{4}{|c|}{ MIC of $\mathrm{Zn}^{2+}(\mathrm{mM})$} & \multicolumn{4}{|c|}{ MIC of $\mathrm{Ni}^{2+}(\mathrm{mM})$} \\
\hline & LB & $\mathrm{MS}+\mathrm{G}$ & $\mathrm{MS}+\mathrm{Ph}$ & $\mathrm{MS}+\mathrm{CN}+\mathrm{Ph}$ & LB & $\mathrm{MS}+\mathrm{G}$ & $\mathrm{MS}+\mathrm{Ph}$ & $\mathrm{MS}+\mathrm{CN}+\mathrm{Ph}$ & LB & $\mathrm{MS}+\mathrm{G}$ & $\mathrm{MS}+\mathrm{Ph}$ & $\mathrm{MS}+\mathrm{CN}+\mathrm{Ph}$ & LB & $\mathrm{MS}+\mathrm{G}$ & $\mathrm{MS}+\mathrm{Ph}$ & $\mathrm{MS}+\mathrm{CN}+\mathrm{Ph}$ \\
\hline$\overline{\mathrm{PhCN}}$ & 2.00 & 1.50 & 1.00 & 0.800 & 1.80 & 1.20 & 1.00 & 0.85 & 1 & 0.9 & 0.60 & 0.50 & 1.2 & 0.9 & 0.6 & 0.4 \\
\hline PhCN1 & 0.05 & 0.04 & 0.03 & 0.015 & 0.04 & 0.03 & 0.02 & 0.01 & 1 & 0.8 & 0.02 & 0.01 & 1.2 & 0.8 & 0.6 & 0.4 \\
\hline $\mathrm{PhCN} 2$ & 2.00 & 1.50 & 0.00 & 0.000 & 1.80 & 1.20 & 0.00 & 0.00 & 1 & 0.8 & 0.00 & 0.00 & 1.2 & 0.9 & 0.0 & 0.0 \\
\hline PhCNM & 0.04 & 0.04 & 0.00 & 0.000 & 0.04 & 0.04 & 0.00 & 0.00 & 1 & 0.7 & 0.00 & 0.00 & 1.2 & 0.8 & 0.0 & 0.0 \\
\hline
\end{tabular}
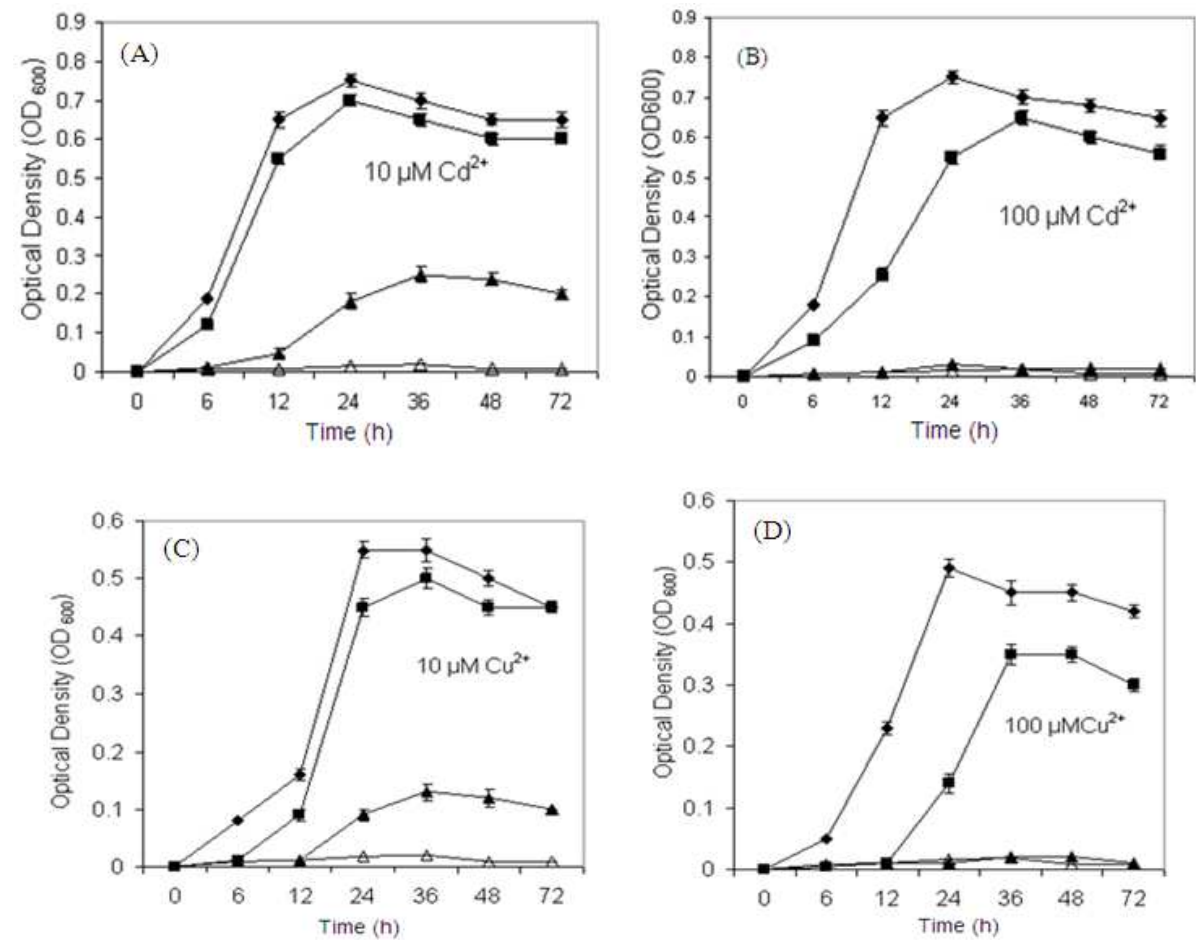

Fig. 1: Effect of cadmium and copper concentrations on the growth of Pseudomonas putida $\mathrm{PhCN}$ and its derivatives in MSM medium amended with phenol and ammonium as a sole carbon and nitrogen sources

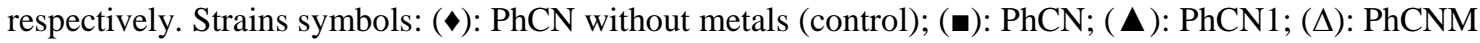

\section{Growth kinetics:}

Biodegradation of the phenol in the absence of heavy metals: Preliminary assays were performed to evaluate the growth rate of wild type strain $\mathrm{PhCN}$ and its derivatives PhCN1 on MSM medium free from heavy metals and supplied with phenol and ammonium or cyanide as a sole source of carbon and nitrogen, respectively. The results shown in Fig. 1A-D indicated that both strains which harbored a catabolic plasmid pPhCN1 were able to degrade the compound with similar rate. However, grown on MSM medium supplied with phenol and cyanide revealed a decrease in the growth rate as well as the rate of phenol consumption comparing with that supplied with ammonium salt as a nitrogen source. Similar findings were reported by ${ }^{[3]}$ for Pseudomonas sp. grown on phenol and cyanide.
Biodegradation of the phenol in the presence of the cadmium: The effect of cadmium on growth parameters and phenol consumption by resistant strain $\mathrm{PhCN}$ (pPhCN1, pPhCN2) and sensitive strain PhCN1 $(\mathrm{pPhCN} 1)$ was investigated. Cadmium at concentration of $10 \mu \mathrm{M}$, did not affect the growth rate of $\mathrm{PhCN}$, whereas, the growth of sensitive strains was significantly reduced comparing with that of the cadmium free medium (Fig. 1A). Moreover, the addition of cadmium at a concentration of $10 \mu \mathrm{M}$ did not change the rate of phenol consumption by resistant strain $\mathrm{PhCN}$, whereas Phenol consumption by sensitive strain PhCN1, was significantly reduced. compared to that of the free-cadmium MSM (Fig. 2A) ${ }^{[2,30]}$.

Increasing concentration of cadmium by ten-fold $(100 \mu \mathrm{M})$ caused a complete inhibition of growth in 
sensitive strain PhCN1 (Fig. 1B), whereas, the growth and Phenol consumption by resistance strain $\mathrm{PhCN}$ was slightly reduced compared to that of the free-cadmium MSM (Fig. 1B and 2B). Previously a similar finding has been reported for the multifunctional strains of Alcaligenes eutrophus that bear plasmids of resistance to bivalent cations, pMOL28 $\left(\mathrm{cnr}-\mathrm{Co}^{\mathrm{r}} \mathrm{N}^{\mathrm{r}}\right)$ and pMOL30

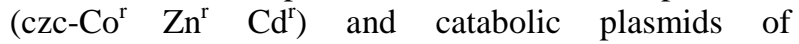
biodegradation of polychlorinated biphenyls, pSS50 $\left(\mathrm{BpH}^{+} / \mathrm{Cbp}^{+}\right)$and 2,4-dichlorophenoxyacetic acid, pJP4 $\left(\mathrm{Tfd}^{+}\right)$are effectively degraded the above pollutants in the presence of metals ${ }^{[6,19]}$.

Biodegradation of phenol in presence of copper: Growth response of the $\mathrm{PhCN}$ and its variant in the presence of cupric chloride was shown in Fig. 1. At low concentration $(10 \mu \mathrm{M})$ in MSM supplemented with phenol and ammonium as a sole source of carbon and nitrogen, respectively, the growth rate of resistant strain $\mathrm{PhCN}$ did not affected, whereas the growth rate of the sensitive strain PhCN1 was significantly reduced (Fig. 1C). Phenol consumption by resistance strain $\mathrm{PhCN}$ was less active compared to the MSM free from copper (Fig. 2C), whereas, phenol consumption by sensitive strain was significantly reduced (Fig. 2C).
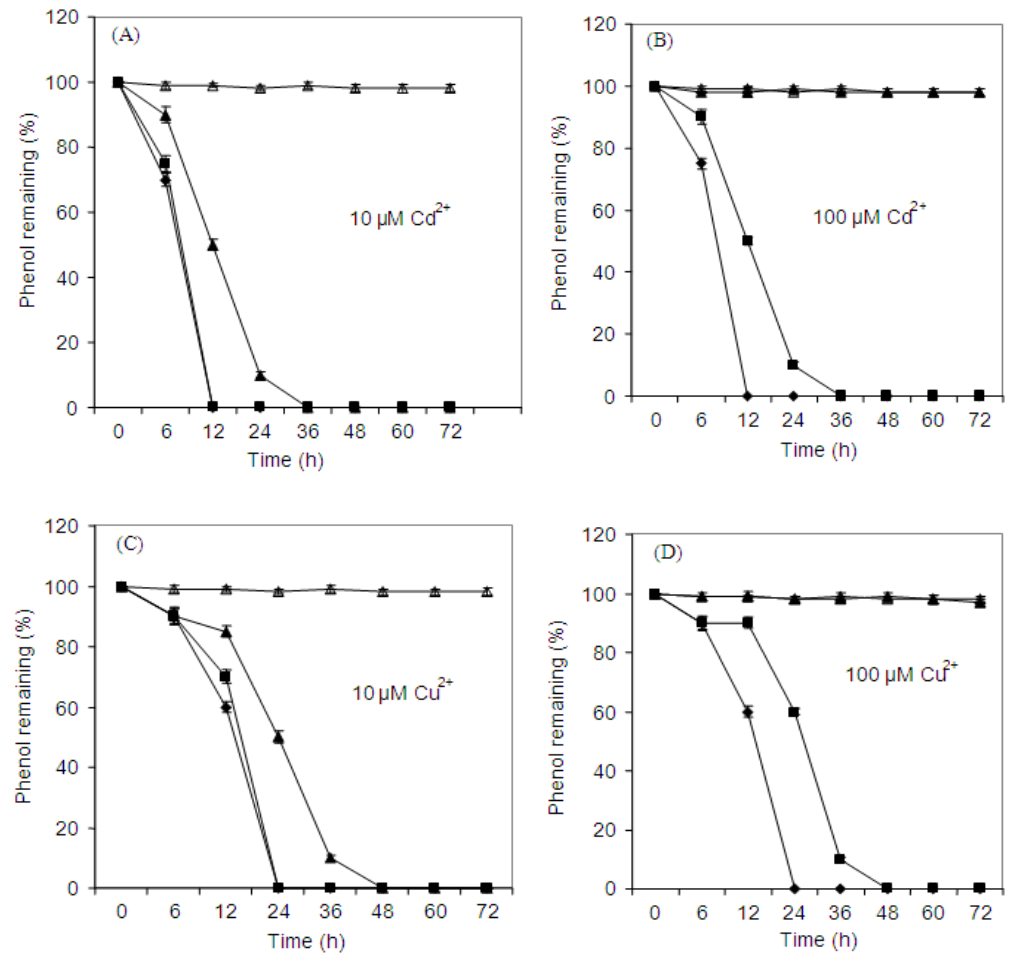

Fig. 2: Effect of cadmium and copper concentrations on the phenol utilization by Pseudomonas putida $\mathrm{PhCN}$ and its

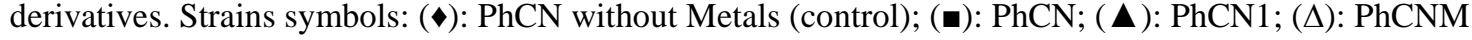



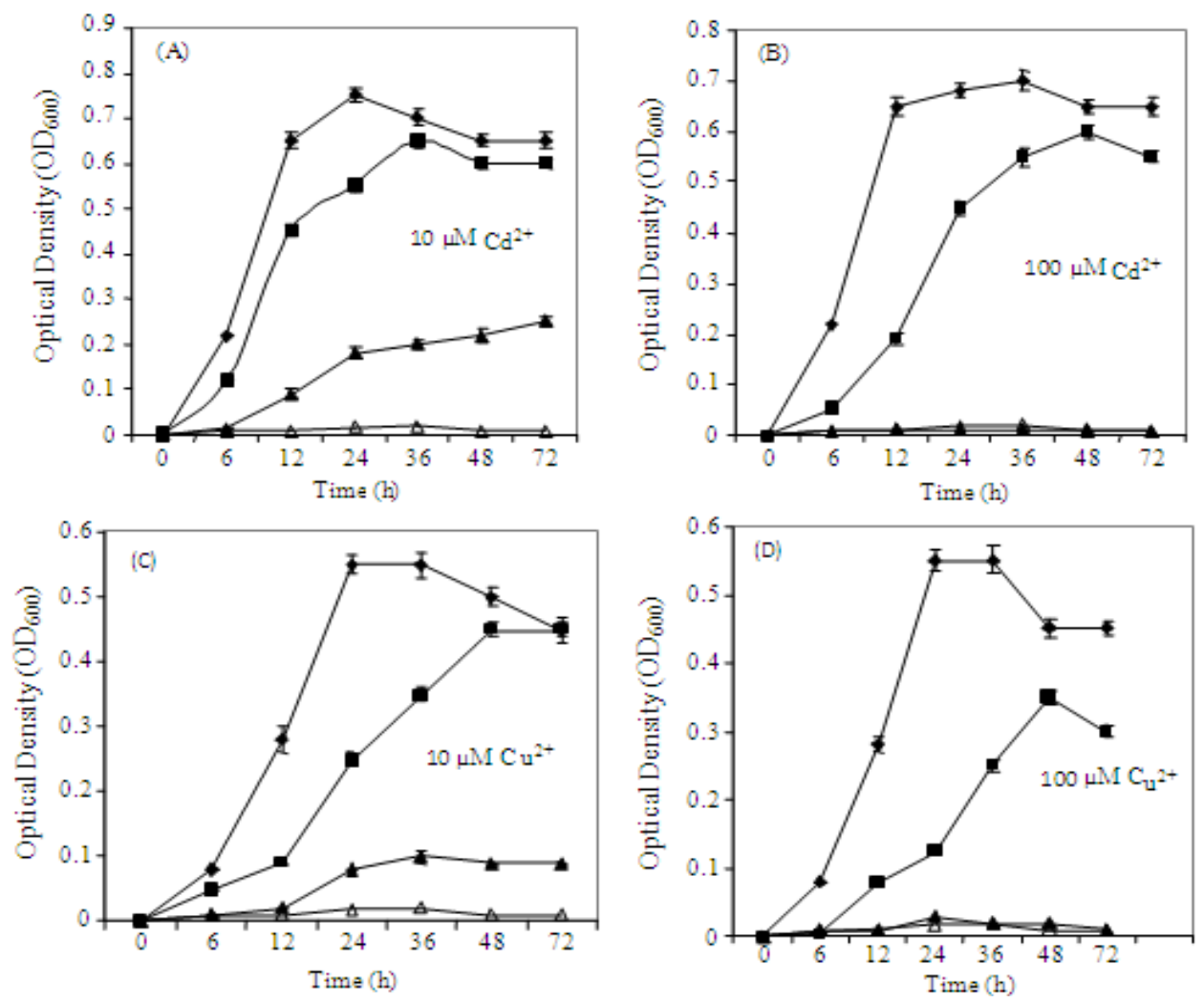

Fig. 3: Effect of cadmium and copper concentrations on the growth of Pseudomonas putida PhCN and its derivatives in MSM medium amended with glucose and cyanide as a sole carbon and nitrogen sources

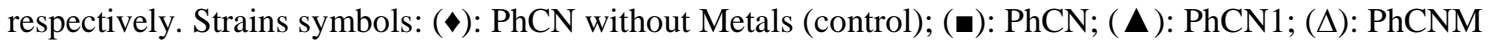

A ten-fold increase of cadmium $(100 \mu \mathrm{M})$ caused a $12 \mathrm{~h}$ lag-phase (Fig. 3B) and cyanide consumption was less active by resistant stain $\mathrm{PhCN}$ compared to that of the MSM free cadmium (Fig. 4B). Under the same conditions, the growth of sensitive strain PhCN1 was completely inhibited (Fig. 3B and 4B). This may be due to the fact that when various toxicants were added together, the growth of almost bacterial isolates was very poor or absent, suggesting that the tolerance level of heavy metal resistance strains is affected by many xenobiotics ${ }^{[8]}$.

Biodegradaion of the cyanide in the presence of the copper: The addition of copper at a concentration $10 \mu \mathrm{M}$ to the MSM containing glucose and cyanide as a sole source of carbon and nitrogen respectively, produced no appreciable affect on the growth and cyanide consumption by resistance variant, while the growth of sensitive strain was significantly reduced (Fig. 3C and 4C).

A ten-fold increase of copper $(100 \mu \mathrm{M})$, caused a long lag-phase $(12 \mathrm{~h})$ and required long time $(60 \mathrm{~h})$ for complete phenol consumption by resistance strain $\mathrm{PhCN}$ (Fig. 3D and 4D). However, the addition of copper at a concentration of $100 \mu \mathrm{M}$ to MSM was completely inhibited the growth of sensitive strain (Fig. 3D and 4D) ${ }^{[31]}$.

By comparing the obtained results in Fig. 1-4, it can be concluded that, low concentration of both $\mathrm{Cu}^{2+}$ and $\mathrm{Cd}^{2+}(10 \mu \mathrm{M})$ did not exhibit any significant inhibitory effect on microbial growth of resistant variants in presence of ammonium or cyanide as a nitrogen source. However, both metals at low concentration significantly reduced the growth of sensitive $\operatorname{strain}^{[30]}$. Ten-fold increase of both metals concentration caused slightly increase a lag phase in the case of resistant variant $\mathrm{PhCN}$ while was completely inhibited the growth of the sensitive strain PhCN1. However, in the presence of $\mathrm{KCN}$ as a nitrogen source, the overall bacterial growth and phenol consumption was less than that observed when the bacteria grew in the presence of ammonium as a nitrogen source. Medium composition affects the degree and pattern of metals inhibition of organic pollutants biodegradation ${ }^{[11]}$. 
Am. J. Biochem. \& Biotech., 5 (2): 84-93, 2009

Table 3: Specific activities of meta-cleaving enzyme C23O dioxygenase in a crude extract of parent strain PhCN and its derivatives grown on different substrate. Enzyme was assayed as described in materials and methods

Substrate (Nitrogen source)

In presence of ammonium ions

In presence of cyanide

\begin{tabular}{|c|c|c|c|c|c|c|c|c|}
\hline \multirow[b]{2}{*}{ Strains } & & \\
\hline & $\mathrm{TSM}+\mathrm{G}$ & $\mathrm{TSM}+\mathrm{Ph}$ & $\mathrm{TSM}+\mathrm{Ph}+\mathrm{Cd}$ & $\mathrm{TSM}+\mathrm{Ph}+\mathrm{Cu}$ & $\mathrm{TSM}+\mathrm{G}$ & $\mathrm{TSM}+\mathrm{Ph}$ & $\mathrm{TSM}+\mathrm{Ph}+\mathrm{Cd}$ & $\mathrm{TSM}+\mathrm{Ph}+\mathrm{Cu}$ \\
\hline$\overline{\mathrm{PhCN}(\mathrm{pPhCN} 1, \mathrm{pPhCN} 2)}$ & 0.01 & 14.2 & 12.2 & 11.4 & 0.01 & 12.8 & 11.6 & 10.8 \\
\hline $\mathrm{PhCN} 1(\mathrm{pPhCN} 1)$ & 0.01 & 14.6 & 0.4 & 0.2 & 0.01 & 10.8 & 0.09 & 0.02 \\
\hline PhCN2 (pPhCN2) & ND & ND & ND & ND & ND & ND & ND & ND \\
\hline PhCNM(Plasmidless) & ND & ND & ND & ND & ND & ND & ND & ND \\
\hline
\end{tabular}

Enzyme activity is given in $\mathrm{U} \mathrm{mg}^{-1}$ of protein. ND: Not Detected; G: Glucose; Ph: Phenol; Cd: Cadmium; Cu: Copper
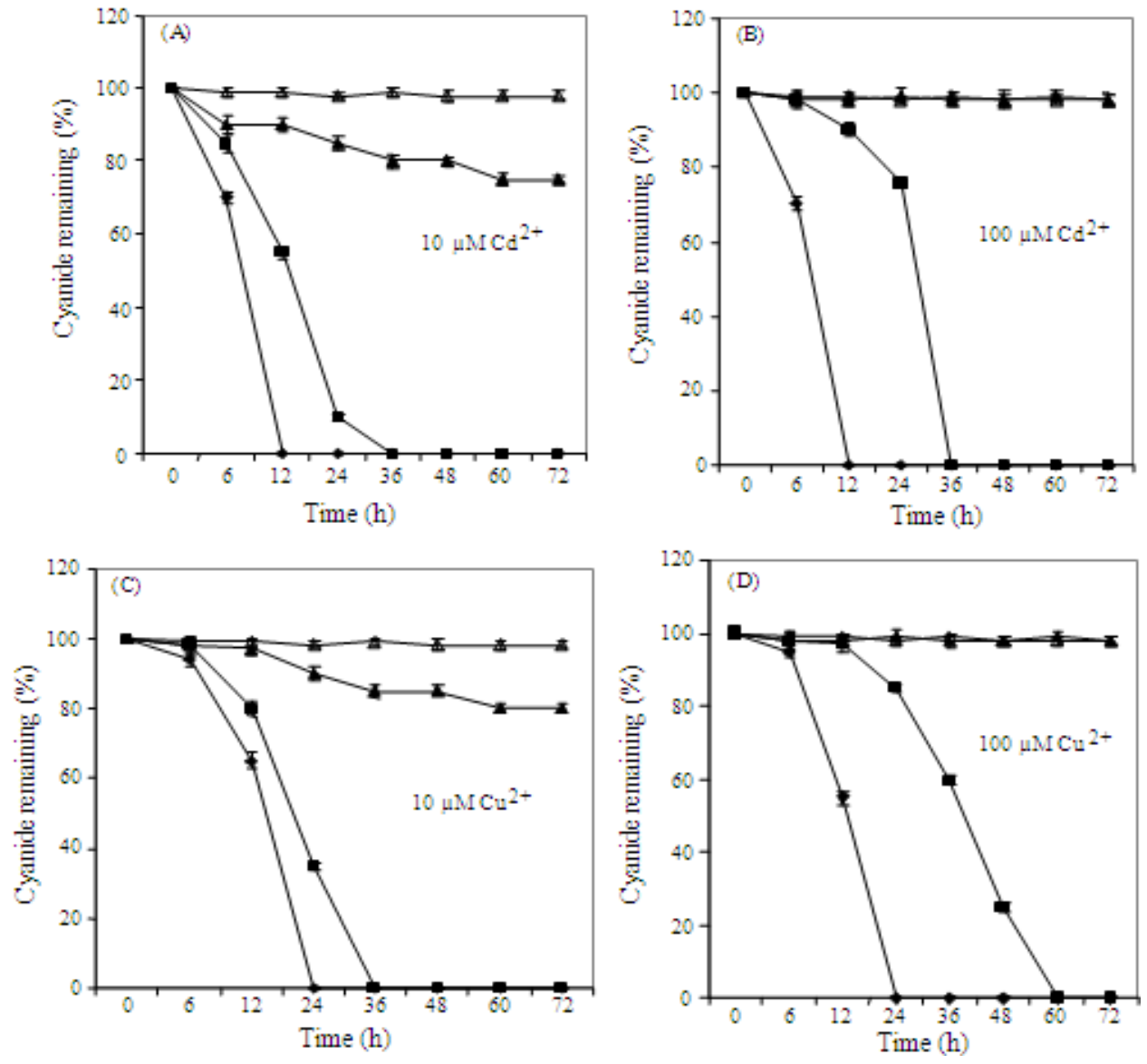

Fig. 4: Effect of copper concentrations on the cyanide utilization by Pseudomonas putida $\mathrm{PhCN}$ and its derivatives. Strains symbols: ( $\bullet$ : PhCN without metals (control);

( $)$ : PhCN; ( $\mathbf{\Delta}):$ PhCN1; $(\Delta):$ PhCNM

Effect of metal ions on the phenol degradation enzyme activity: The $\mathrm{C} 23 \mathrm{O}$ pathway for catechol degradation during phenol metabolism in Pseudomonas sp. PhCN was previously demonstrated ${ }^{[9]}$. When the activity of $\mathrm{C} 23 \mathrm{O}$ enzyme was measured as described in Materials and Methods, no $\mathrm{C} 23 \mathrm{O}$ activity was detected in LB medium in the absence of phenol. In the presence of phenol, the activity of $\mathrm{C} 23 \mathrm{O}$ was negligible (Table 3).
In the absence of heavy metals, the $\mathrm{C} 23 \mathrm{O}$ activity was high when the cells were grown in the presence of phenol and ammonium salt as a sole source of carbon and nitrogen respectively (Table 3 ). In the presence of $\mathrm{KCN}$ as a nitrogen source, the overall enzyme activity was less than that observed in the presence of ammonium as a nitrogen source (Table 3 ).

The effect of $\mathrm{Cd}^{2+}$ or $\mathrm{Cu}^{2+}$ on the 2,3-dioxygenase enzyme activity in the MSM containing phenol and 
ammonium as a sole source of carbon and nitrogen respectively, was investigated. The results in Table 3 showed that both the metals had severely inhibitory effect on the 2,3-dioxygenase activity in the sensitive strain while they had slight effect on the enzyme activity in resistant strain $\mathrm{PhCN}^{[22,35]}$. The effect of $\mathrm{Cd}^{2+}$ or $\mathrm{Cu}^{2+}$ was also found to exert a strong inhibitory effect on the enzyme activity in the presence of cyanide as a nitrogen source (Table 3 ). This could be attributed to enzymes produced into the extracellular environment often face higher concentration of metals, since they are not protected by cell-associated metal-detoxification mechanisms ${ }^{[35]}$.

\section{CONCLUSION}

Multifunctional strain of Pseudomonas putida strain $\mathrm{PhCN}$ that bear plasmids of resistance to bivalent cations, pPhCN2 $\left(\mathrm{Cd}^{\mathrm{r}}, \mathrm{Cu}^{\mathrm{r}}\right)$ and catabolic plasmids of biodegradation of phenol pPhCN1 $\left(\mathrm{Ph}^{+}\right)$are effectively degraded the above pollutants in the presence of metals as compared with sensitive strain. The effect of $\mathrm{Cd}^{2+}$ or $\mathrm{Cu}^{2+}$ was also found to exert a strong inhibitory effect on the $\mathrm{C} 23 \mathrm{O}$ dioxygenase enzyme activity in the presence of cyanide as a nitrogen source. However, the presence of heavy metal resistance plasmid alleviated the inhibitory effect of metals on the enzyme activity in resistant strain. These findings demonstrate the possibility of combining the plasmids of phenol catabolism, plasmids of resistance to heavy metals and systems of chromosomal gene encoded for cyanide assimilation. This approach can be used for the creation of polyfunctional bacterial strains effective for bioremediation of soil polluted by phenol in combination with cyanide and heavy metals.

\section{REFERENCES}

1. Al-Saleh, E. and C. Obuekwe, 2005. Inhibition of hydrocarbon bioremediation by lead in a crude oilcontaminated soil. Int. Biodeteriorat. Biodegrad., 56: 1-7. DOI: 10.1016/J.IBIOD.2004.11.003

2. Amor, L., C. Kennes and M.C. Veiga, 2001. Kinetics of inhibition in the biodegradation of monoaromatic hydrocarbons in the presence of heavy metals. Biores. Technol., 78: 181-185. DOI: 10.1016/S0960-8524(00)00182-6

3. Arutchelvan, A., V. Kanakasabai, S. Nagarajan and V. Muralikrishnan, 2005. Isolation and identification of novel high strength phenol degrading bacterial strains from phenol formaldehyde resin manufacturing industrial wastewater. J. Hazard. Mater., B27: 238-243. DOI: 10.1016/J.JHAZMAT.2005.04.043
4. Barbieri, P., G. Bestetti, D. Reniero and E. Galli, 1996. Mercury resistance in aromatic compounds degrading Pseudomonas strains. FEMS Microbiol. Ecol., 20: 185-194. http://cat.inist.fr/?aModele=afficheN\&cpsidt=3159354

5. Benka-Coker, M.O. and J.A. Ekundayo, 1998. Effects of heavy metals on growth of species of Micrococus and Pseudomonas in a crude oil/mineral salts medium. Biores. Technol., 66: 241-245. DOI: 10.1016/S0960-8524(00)00182-6

6. Collard, J.M., P. Corbisier, L. Diels, Q. Dong and C. Jeanthon et al., 1994. Plasmids for heavy metal resistance in Alcaligens eutrophus CH34: Mechanisms and application. FEMS Microbiol. Rev., 14: 405-414.

http://www.ncbi.nlm.nih.gov/pubmed/7917428

7. Chen, X., J. Shi, Y. Chen, X. Xu, S. Xu and Y. Wang, 2005. Tolerance and bisorption of copper and zinc by Pseudomonas putida CZ1 isolated from metal polluted soil. Can. J. Microbiol., 52: 308-316. DOI: 10.1139/W05-157

8. De, J., N. Ramaiah, A. Mesquita and X.N. Verleker, 2003. Tolerance to various Toxicants by Marine bacteria highly resistant to mercury. Mar. Biotechnol., 5: 185-193. DOI: 10.1007/s10126-0020061-6

9. El-Deeb, A.B., 2006. Plasmid-and chromosomemediated assimilation of phenol and cyanide in Pseudomonas sp. strain PhCN. J. Microbiol. Biotechnol., 16: 1068-1077.

http://cat.inist.fr/?aModele $=$ afficheN\&cpsidt $=1809$ 3101

10. Folsom, B.R., P.J. Chapman and R. Pritchard, 1990. Phenol and trichloroethylene degradation by Pseudomonas cepacia 4: Kinetics and interaction between substrates. Applied Environ. Microbiol., 56: 1279-1285.

http://www.pubmedcentral.nih.gov/articlerender.fc gi?artid=184395

11. Hoffman, R.D., J.L. Okon and T.R. Sandrin, 2005. Medium composition affects the degree and pattern of cadmium inhibition of naphthalene biodegradation. Chemosphere, 59: 919-927. DOI: 10.1016/J.CHEMOSPHERE.2004.11.057

12. Hong, B.H., Y.S. Chang, I.H. Nam, P. Fortnagel and S. Schmit, 2002. Biotransformation of 2,7dichloro-and 1, 2, 3, 4-tetrachlorodibenzo-p-dioxin by Sphingomonas wittichii RW1. Applied Environ. Microbiol., 68: 2584-2588. DOI: 10.1128/AEM.68.5.2584-2588.2002

13. Jain, R.K. and G.S. Sayler, 1987. Problems and potential for in situ treatment of environmental pollutants by engineered microorganisms. Microbiol. Sci., 4: 59-63. http://www.ncbi.nlm.nih.gov/pubmed/3153173 
14. Kado, C.I. and S.T. Liu, 1981. Rapid procedure for detection and isolation of large and small plasmids. J. Bacteriol., 145: 1365-1373. http://www.ncbi.nlm.nih.gov/pubmed/7009583

15. Kuo, C.W. and B.R. Sharak Genthner, 1996. Effect of added heavy metals ions on biotransformation and biodegradation of 2-chlorophenol and 3chlorobenzoate in anaerobic bacterial consortia. Applied Environ. Microbiol., 62: 2317-2323. http://www.pubmedcentral.nih.gov/articlerender.fc gi? artid=1388889

16. Lin, W.C., Y.S. Chen and W.Y. Cheng, 2006. Effect of metals on biodegradation kinetics for methyl tert-butyl ether. J. Biochem. Eng., 32: 25-32. DOI: 10.1016/J.BEJ.2006.07.010

17. Lowery, O.H., N.J. Rosenbrough, R.L. Farr and R.J. Randall, 1951. Protein measurement with the Folin phenol reagent. J. Biol. Chem., 193: 265-275. http://www.ncbi.nlm.nih.gov/pubmed/14907713

18. Malakul, P., K.R. Srinivasan and H.Y. Wang, 1998. Metal toxicity reduction in naphthalene biodegradation by use of metal-chelation adsorbents. Applied Environ. Microbiol., 64: 4610-4613. http://www.pubmedcentral.nih.gov/articlerender.fc gi? artid=106694

19. Mergeay, M., 1995. Heavy Metal Resistances in Microbial Ecosystems. In: Molecular Microbiol Ecology Manual, Akkermans, A.D.L., F.J. de Bruijn, J.D. van Elsas and J.T. Trevors (Eds.). Kluwer Academic Publishers, Dordrecht, pp: 1-17.

20. Mergeay, M., D. Nies, H.G. Schiegel, J. Gerits, P. Charles and F. Van Gijsegem, 1985. Alcaligenes eutrophus $\mathrm{CH} 34$ is a facultative chemolithotroph with plasmid-bound resistance to heavy metals. J. Bacteriol., 162: 328-334. http://www.pubmedcentral.nih.gov/articlerender.fc gi? artid=218993

21. Myers, P.R., P. Gokool, E. Rawling and D.R. Woods. 1991 An efficient Cyanide-degrading Bacillus pumilus strain. J. Gen. Microbiol. 137: 1397-1400.

http://cat.inist.fr/?aModele $=$ afficheN\&cpsidt $=1152$ 4872

22. Nakazawa, T. and A. Nakazawa, 1970. Pyrocatechase (Psueudomonas). Method Enz., 17A: 518.

23. Norena-Barroso, E., R. Sima-Lvarez, G. Gold-Bouchot and O. Zapata-Perez, 2004. Persistent organic pollutants and histological lesions in Mayan catfish Ariopsis assimilis from the Bay of Chetumal. Mexico. Mar. Pollut. Bull., 48: 263-269. http://www.ncbi.nlm.nih.gov/pubmed/14972578
24. Riis, V., W. Babel and H.O. Pucci, 2002. Influence of heavy metals on the microbial degradation of diesel fuel. Chemosphere, 49: 559-568. DOI: 10.1016/S0045-6535(02)00386-7

25. Roane, T.M., J.L. Josephson and I.L. Pepper, 2001. Dual-bioaugmentation strategy to enhance remediation of co-contaminated soil. Applied Environ. Microbiol., 67: 3208-3215. DOI: 10.1128/AEM.67.7

26. Roane T. M, K. L Josephson, I. L. Pepper, 1997. Microbial remediation of soils co-contaminated with 2,4-dichlorophenoxy acetic acid and cadmium. In: 12th Annual Conference on Hazardous Waste Research: Building Partnerships for Innovative Technologies, 19-22 May 1997, Kansas City, MO, USA., pp: 343-356. http://www.engg.ksu.edu/HSRC/97abstracts/doc77 .html

27. Said, W.A. and D.L. Lewis, 1991. Quantitative assessment of the effects of metals on microbial degradation of organic chemicals. Applied Environ. Microbiol., 57: 1498-1503. http://www.pubmedcentral.nih.gov/articlerender.fc gi? $\operatorname{artid}=182975$

28. Sambrook, J., E.F. Fritsch and T. Maniatis, 1989. Molecular Cloning: A Laboratory Manual. 2nd Edn., Cold Spring Harbor Laboratory Press Cold Spring Harbor, New York.

29. Silva, A.D.A., P.M. Pereira, S.G. Filho and E. Hofer, 2007. Utilization of phenol in the presence of heavy metals by metal-tolerant non-fermentative gram-negative bacteria isolated from wastewater. Microbiologia, 49: 68-73. http://www.medigraphic.com/pdfs/lamicro/mi2007/mi07-3_4e

30. Siunova, V.T., T.O. Anokhina, A.V. Mashukova, V.V. Kochetkov and A.M. Boronin, 2007. Rhizosphere strain Pseudomonas chlororaphis capable of degrading naphthalene in the presence of cobalt/nickel. Microbiology, 76: 182-188. DOI: 10.1134/S0026261707020099

31. Sokhn, J., F.A.A.M. De Leij, T.D. Hart and T. Lynch, 2001. Effect of copper on the degradation of phenanthrene by soil micro-organism. Lett. Applied Microbiol., 33: 164-168. DOI: 10.1046/j.1472-765x.2001.00972

32. Springael, D., L. Diels, H. Hooyberghs, S. Krepsk and M. Mergeay, 1993. Construction and characterization of heavy metal resistant haloaromatic-degrading Alcaligenes eutrophus strains. Applied Environ. Microbiol., 59: 334-339. http://aem.asm.org/cgi/content/abstract/59/1/334 
33. Wasi, S., G. Jeelani and M. Ahmad, 2008. Biochemical characterization of a multiple heavy metal, pesticides and phenol resistant Pseudomonas fluorescens strain. Chemosphere, 71: 1348-1355.

10.1016/J.CHEMOSPHERE.2007.11.023

34. White, V.E. and C.J. Knowles, 2003. Degradation of cooper-NTA by Mesorhizobium sp. NCIMB 13524. Internat. Biodeteriorat. Biodegradat., 52: 143-150. DOI: 10.1016/S0964-8305(03)00049-0
35. Yeom, H.S. and J.Y. Yoo, 1997. Overcoming the inhibition effects of metal ions in the degradation of benzene and toluene by Alcaligenes xylosoxidans Y234. Kor. J. Chem. Eng., 14: 204-208. DOI: $10.1007 / \mathrm{BF} 02706096$ 